\title{
English Language
}

National Cancer Institute

\section{Source}

National Cancer Institute. English Language. NCI Thesaurus. Code C82847.

An Indo-European language belonging to the West Germanic branch; the official

language of Britain and the United States, and most of the Commonwealth countries. 